Article

\title{
The Influence of the Ratio of Nitrate to Ammonium Nitrogen on Nitrogen Removal in the Economical Growth of Vegetation in Hybrid Constructed Wetlands
}

\author{
Haq Nawaz Abbasi ${ }^{1,2}$, Viliana Vasileva ${ }^{3}$ and Xiwu Lu ${ }^{1, *}$ \\ 1 School of Energy and Environment, Southeast University, Nanjing 210096, China; hn.abbasi@fuuast.edu.pk \\ 2 Department of Environmental Science, Federal Urdu University, Karachi 75000, Pakistan \\ 3 Institute of Forage Crop, 89 “General Vladimir Vazov" Str., Pleven 5800, Bulgaria; \\ viliana.vasileva@gmail.com \\ * Correspondence: xiwulu@seu.edu.cn; Tel.: +86-139-1475-3816
}

Academic Editor: Yu-Pin Lin

Received: 14 December 2016; Accepted: 15 March 2017; Published: 17 March 2017

\begin{abstract}
Growing vegetables economically in the use of constructed wetland for wastewater treatment can play a role in overcoming water and food scarcity. Allium porrum L., Solanum melongena L., Ipomoea aquatica Forsk., and Capsicum annuum L. plants were selected to grow in hybrid constructed wetland $(\mathrm{CW})$ under natural conditions. The impact of the ratio of nitrate to ammonium nitrogen on ammonium and nitrate nitrogen removal and on total nitrogen were studied in wastewater. Constructed wetland planted with Ipomoea aquatica Forsk. and Solanum melongena L. showed higher removal efficiency for ammonium nitrogen under higher ammonium concentration, whereas Allium porrum L.-planted CW showed higher nitrate nitrogen removal when $\mathrm{NO}_{3}-\mathrm{N}$ concentration was high in wastewater. Capsicum annuum L.-planted CW showed little efficiency for both nitrogen sources compared to other vegetables.
\end{abstract}

Keywords: constructed wetland; $\mathrm{NO}_{3}-\mathrm{N} / \mathrm{NH}_{4}-\mathrm{N}$ ratio; nitrogen removal; wastewater; $\mathrm{CFW}$

\section{Introduction}

Wastewater can pollute receiving water bodies and thus need to be treated beforehand [1]. The conventional treatment processes are expensive to build especially for areas of low socioeconomic status [2]. Therefore, cost-effective and environmentally sound methods of treating wastewaters are needed. Constructed wetlands have gained popularity from the last several years and have been used as an alternative to conventional wastewater treatment methods [3] because of their easy maintenance and operation, low energy consumption, and water recyclability $[4,5]$. Constructed wetlands are successfully used to treat different types of wastewater [6-13]. Currently, the world population is on the edge of scarcity for water and food; therefore, the recycling of water and nutrients (in wastewater) are emerging as integral parts of water and food demand management [14]. Growing vegetation economically in the use of constructed wetlands for wastewater treatment is therefore needed and can help to reduce the gap between supply and demand [15].

Plants take up nitrogen in the form of $\mathrm{NO}_{3}-\mathrm{N}$ (nitrate) or $\mathrm{NH}_{4}-\mathrm{N}$ (ammonium); therefore, the total $\mathrm{N}$ (nitrogen) absorbed usually consists of a combination of these two forms [16,17]. The ratio of $\mathrm{NO}_{3}-\mathrm{N}$ to $\mathrm{NH}_{4}-\mathrm{N}$ is of a great significance and can impact plant growth. The optimum growth of plants species required a different ratio of nitrate to ammonium $\mathrm{N}$. The best ratio to be applied also varies with other factors such as growth stage, temperature, $\mathrm{pH}$, and soil properties [18]. $\mathrm{NH}_{4}-\mathrm{N}$ in ionic form can compete with other forms (potassium, calcium, magnesium) for uptake by the roots [19]. 
An unbalanced $\mathrm{NO}_{3}-\mathrm{N}$ to $\mathrm{NH}_{4}-\mathrm{N}$ ratio may affect solubility and availability of other nutrients by changing the $\mathrm{pH}$ near the roots [20].

Several researchers have reported that $\mathrm{NH}_{4}-\mathrm{N}$ as a sole source of $\mathrm{N}$ is deleterious to the growth of many higher plants [21], and a higher concentration than $\mathrm{NO}_{3}-\mathrm{N}$ can limit the growth of plants [22,23]. In several crops, combinations of both forms $\left(\mathrm{NH}_{4}-\mathrm{N}\right.$ and $\left.\mathrm{NO}_{3}-\mathrm{N}\right)$ usually result in elevated growth compared to when either $\mathrm{N}$ form is used alone [24-26]. However, some plant species showed better growth when $\mathrm{NH}_{4}-\mathrm{N}$ was the $\mathrm{N}$ source [27]. In a controlled environment, some plants absorb $\mathrm{NO}_{3}-\mathrm{N}$ more rapidly [28], whereas other plants prefer $\mathrm{NH}_{4}-\mathrm{N}$ [21]. The absorption rates of $\mathrm{NO}_{3}-\mathrm{N}$ and $\mathrm{NH}_{4}-\mathrm{N}$ are influenced by the ratio of $\mathrm{NO}_{3}-\mathrm{N}$ to $\mathrm{NH}_{4}-\mathrm{N}$ [29]. In several plant species, $\mathrm{NH}_{4}-\mathrm{N}$ may compete with $\mathrm{NO}_{3}-\mathrm{N}$ and inhibit $\mathrm{NO}_{3}-\mathrm{N}$ absorption in the presence of both $\mathrm{NO}_{3}-\mathrm{N}$ and $\mathrm{NH}_{4}-\mathrm{N}$ [30]. However, there is no information available on the $\mathrm{NO}_{3}-\mathrm{N} / \mathrm{NH}_{4}-\mathrm{N}$ ratio on plants species when grown in a constructed wetland with natural environment. The objective of this study was to improve the constructed wetland system for the economical growth of vegetation by examining the influence of the ratio of nitrate to ammonium $\mathrm{N}$ on $\mathrm{N}$ removal in wastewater post-treatment.

\section{Materials and Methods}

\subsection{Experimental Site and Constructed Wetland}

The research was conducted at the Southeast University campus, New District, Wuxi, China. The total area of constructed wetland is $100 \mathrm{~m}^{2}$. The Wuxi has four distinct seasons and exist in a north subtropical humid monsoon climate zone, with rich rainfalls and sunshine. The average perennial temperature over 30 years (1981-2010) is $16.2^{\circ} \mathrm{C}$, and the average precipitation is $1121.7 \mathrm{~mm}$, with 123 days of rain and $1924.3 \mathrm{~h}$ of sunshine [31]. Two pilot-scale hybrid constructed wetland systems were established for experimental plants. The hybrid system was a combination of Constructed Floating Treatment Wetlands (CFW) and horizontal flow constructed wetlands (HFCW). Each bed in each unit was $2.5 \mathrm{~m} \times 0.3 \mathrm{~m} \times 0.5 \mathrm{~m}$ (length $\times$ width $\times$ height) made of concrete and lined with epoxy. The first bed was designed for CFW without a substrate, whereas a second bed of each unit was packed with a $10 \mathrm{~cm}$ supporting layer of large gravel $(30-40 \mathrm{~mm}), 25 \mathrm{~cm}$ of ceramsite $(10-20 \mathrm{~mm}$ in diameter), and $10 \mathrm{~cm}$ of small gravel $(10-20 \mathrm{~mm})$. The wastewater entered in the first bed from the distribution channel, that was connected to a wastewater tank, and flow was controlled by value.

Four different types of plants were selected (Table 1) to grow in the constructed wetland, and selections were made keeping in mind the economic value of the vegetables, their easy availability in the local market, their aesthetic worth, and their ability to adapt in existing climatic conditions. Polyethylene foam boards were used for planting as floating mats in the CFW beds, and $2 \mathrm{~cm}$ holes were perforated for each plant. The systems were inspected on a daily basis. Special attention was paid to the inlet and outlet flows, as suspended solid-present wastewater can cause obstruction in the pipes.

Table 1. Selected plant species for experiments.

\begin{tabular}{cccc}
\hline Number & Common Name & Scientific Name & Used Name \\
\hline 1 & Leek & Allium porrum L. & A. porrum \\
2 & Egg Plant & Solanum melongena L. & S. melongena \\
3 & Water spinach & Ipomoea aquatica Forsk. & I. aquatica \\
4 & Hot pepper & Capsicum annum L. & C. annumm L. \\
\hline
\end{tabular}

\subsection{Experimental Conditions}

The experiment was carried out in the natural environment, and sewage was treated through A2O (anaerobic/anoxic/oxic) system and then artificially stimulated before being introduced into the constructed wetland. Two setups of the hybrid system were established. In the first setup, the CFW beds were planted with A. porum, and the HFCW beds were planted with S. melongena; in the second setup, I. aquatica and C. annum L were planted in the CFW and HFCW beds, respectively. 
The selection of plants for each setup was random. Potassium nitrate $\left(\mathrm{KNO}_{3}\right)$ as $\mathrm{NO}_{3}-\mathrm{N}$, ammonium bicarbonate $\left(\mathrm{NH}_{4} \mathrm{HCO}_{3}\right)$ as $\mathrm{NH}_{4}-\mathrm{N}$, potassium dihydrogen $\left(\mathrm{KH}_{2} \mathrm{PO}_{4}\right)$ as total phosphorus, and glucose $\left(\mathrm{C}_{6} \mathrm{H}_{12} \mathrm{O}_{6}\right)$ as a source of chemical oxygen demand were used, whereas micronutrients were added according to Zhang et al. [32]. The $\mathrm{pH}$ was adjusted to $6.0 \pm 0.2$ with dilute $\mathrm{NaOH}$ or $\mathrm{HCl}$. These constructed wetlands (CWs) ran for 20 days to achieve stabilization for further experiments, and the $\mathrm{NO}_{3}-\mathrm{N} / \mathrm{NH}_{4}-\mathrm{N}$ ratio was adjusted and divided into four experimental runs (ERs) (Table 2). The hydraulic load was $0.2 \mathrm{~m} \cdot \mathrm{d}^{-1}$ and the hydraulic retention time was $1.25 \mathrm{~d}$. The average DO in influent and effluent was $1-5 \mathrm{mg} \cdot \mathrm{L}^{-1}$ and $0-2 \mathrm{mg} \cdot \mathrm{L}^{-1}$, respectively. The quality of wastewater was measured at each step on a routine basis.

Table 2. Average influent stimulated wastewater quality of during experimental runs.

\begin{tabular}{ccccccc}
\hline \multirow{2}{*}{ Experimental Run (ER) } & $\mathbf{N O}_{3}-\mathbf{N} / \mathbf{N H}_{\mathbf{4}}-\mathbf{N}$ & $\mathbf{N O}_{3}-\mathbf{N}$ & $\mathbf{N H}_{\mathbf{4}}-\mathbf{N}$ & $\mathbf{T N}$ & $\mathbf{T P}$ & $\mathbf{C O D}$ \\
\cline { 2 - 7 } & $5: 1$ & 24.69 & $\mathbf{m g} \cdot \mathbf{L}^{-\mathbf{1}}$ \\
\hline 1 & $2: 1$ & 20.99 & 9.83 & 29.51 & 3.05 & 89.14 \\
2 & $1: 1$ & 14.28 & 14.93 & 30.10 & 2.92 & 91.25 \\
3 & $1: 2$ & 9.90 & 19.94 & 29.83 & 2.91 & 98.63 \\
4 & &
\end{tabular}

\subsection{Analytical Methods}

Standard methods [33] were used to analyze ammonium $\left(\mathrm{NH}_{4}-\mathrm{N}\right)$, nitrate $\left(\mathrm{NO}_{3}-\mathrm{N}\right)$, total nitrogen (TN), total phosphorus (TP), and chemical oxygen demand (COD) parameters in wastewater, whereas DO and $\mathrm{pH}$ was measured by DO200 and PH100 probes (YSI), respectively.

\subsection{Statistical Method}

MS Excel (Office package-16) and SPSS version-18.0 (SPSS incorporation, Chicago, IL, USA) were used for data analysis and presentation.

\section{Results}

\section{1. $\mathrm{NH}_{4}-\mathrm{N}$ Removal under Different $\mathrm{NO}_{3}-\mathrm{N} / \mathrm{NH}_{4}-\mathrm{N}$ Ratios}

The impact of the $\mathrm{NO}_{3}-\mathrm{N} / \mathrm{NH}_{4}-\mathrm{N}$ ratio on the removal of $\mathrm{NH}_{4}-\mathrm{N}$ is shown in Figures 1 and 2. For the first setup, the removal efficiency in the first bed was $76.93 \%, 63.94 \%, 30.60 \%$, and $40.75 \%$, and in the second bed, the removal efficiency was $90.03 \%, 87.88 \%, 73.64 \%$, and $74.74 \%$, whereas for the second setup, removal efficiency was $88.89 \%, 75.93 \%, 63.99 \%$, and $58.79 \%$ and $89.23 \%, 82.84 \%$, $69.72 \%$, and $73.65 \%$ in Beds 1 and 2, respectively. $\mathrm{NH}_{4}-\mathrm{N}$ removal efficiency was significant $(p>0.05)$ (Table 3). There was no significant difference between the two units for $\mathrm{NH}_{4}-\mathrm{N}$ removal under different $\mathrm{NO}_{3}-\mathrm{N} / \mathrm{NH}_{4}-\mathrm{N}$ ratios. 


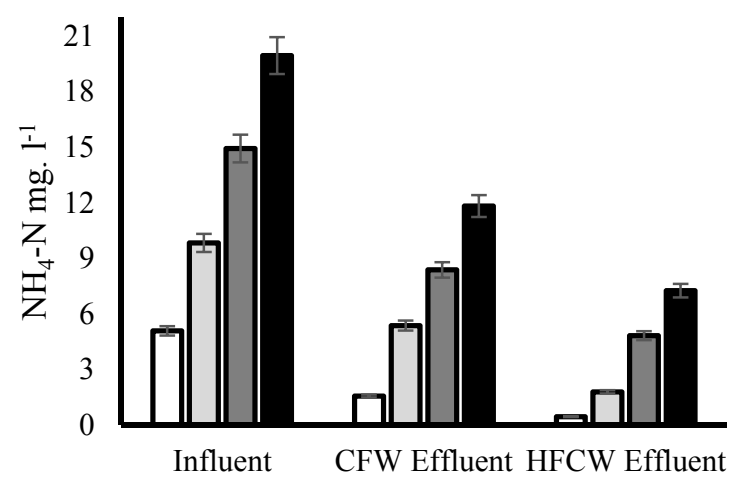

Sampling Locations

$\begin{array}{lll}\square & \text { ER 1 } & \text { ER 2 } \\ \square & \text { ER 3 } & \text { ER 4 }\end{array}$

Figure 1. $\mathrm{NH}_{4}-\mathrm{N}$ concentration during different experimental runs in the first setup.

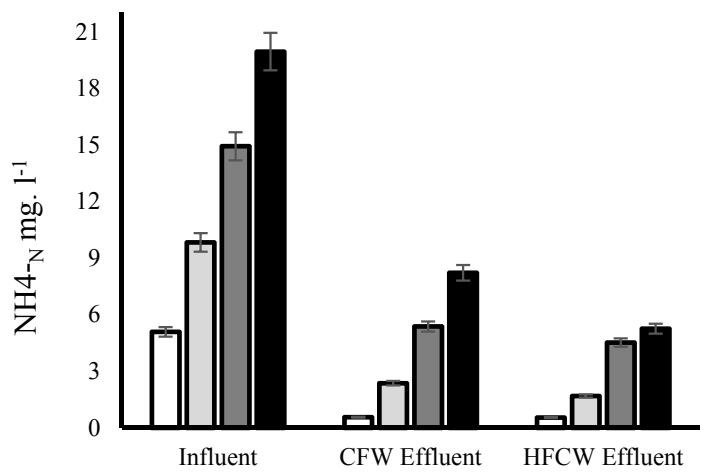

Sampling Locations

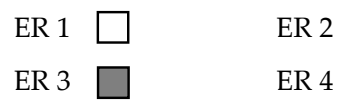

Figure 2. $\mathrm{NH}_{4}-\mathrm{N}$ concentration during different experimental runs in the second setup.

Table 3. Estimated values of effluent during different ERs in Setups 1 and 2.

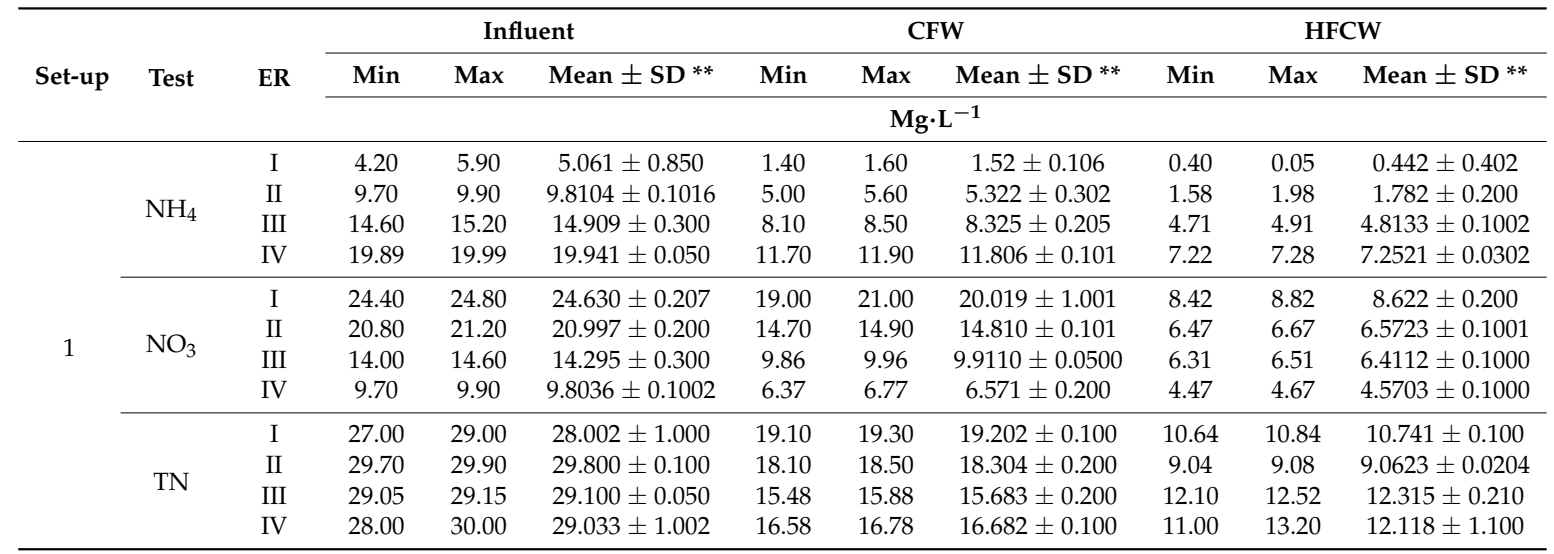

** probability value $>0.001$. 
Table 3. Cont.

\begin{tabular}{|c|c|c|c|c|c|c|c|c|c|c|c|}
\hline \multirow{3}{*}{ Set-up } & \multirow{3}{*}{ Test } & \multirow{3}{*}{ ER } & \multicolumn{3}{|c|}{ Influent } & \multicolumn{3}{|c|}{ CFW } & \multicolumn{3}{|c|}{ HFCW } \\
\hline & & & Min & $\operatorname{Max}$ & Mean \pm SD $^{* *}$ & Min & Max & Mean \pm SD ** & Min & $\operatorname{Max}$ & Mean $\pm S D * *$ \\
\hline & & & \multicolumn{9}{|c|}{$\mathrm{Mg} \cdot \mathrm{L}^{-1}$} \\
\hline \multirow{12}{*}{2} & \multirow{4}{*}{$\mathrm{NH}_{4}$} & I & 4.20 & 5.90 & $5.061 \pm 0.850$ & 0.30 & 0.80 & $0.555 \pm 0.250$ & 0.34 & 0.74 & $0.543-0.200$ \\
\hline & & II & 9.70 & 9.83 & $9.8104 \pm 0.1016$ & 2.25 & 2.45 & $2.3553 \pm 0.1004$ & 1.40 & 1.80 & $1.629 \pm 0.206$ \\
\hline & & III & 14.60 & 15.20 & $14.909 \pm 0.300$ & 5.07 & 5.67 & $5.372 \pm 0.300$ & 4.30 & 4.70 & $4.507 \pm 0.200$ \\
\hline & & IV & 19.89 & 19.99 & $19.941 \pm 0.050$ & 8.10 & 8.30 & $8.2064 \pm 0.1006$ & 4.20 & 6.20 & $5.252 \pm 1.000$ \\
\hline & \multirow{4}{*}{$\mathrm{NO}_{3}$} & I & 24.40 & 24.80 & $24.630 \pm 0.207$ & 14.29 & 16.29 & $15.293 \pm 1.000$ & 9.70 & 11.70 & $10.709 \pm 1.000$ \\
\hline & & II & 20.80 & 21.20 & $20.997 \pm 0.200$ & 9.56 & 11.56 & $10.561 \pm 1.000$ & 6.60 & 8.60 & $7.623 \pm 1.001$ \\
\hline & & III & 14.00 & 14.60 & $14.295 \pm 0.300$ & 7.42 & 7.82 & $7.620 \pm 0.200$ & 6.00 & 6.41 & $6.209 \pm 0.205$ \\
\hline & & IV & 9.70 & 9.90 & $9.8036 \pm 0.1002$ & 3.10 & 5.10 & $4.103 \pm 1.000$ & 4.70 & 5.30 & $5.013 \pm 0.301$ \\
\hline & \multirow{4}{*}{$\mathrm{TN}$} & I & 27.00 & 29.00 & $28.002 \pm 1.000$ & 17.75 & 21.75 & $19.75 \pm 2.00$ & 7.95 & 8.64 & $8.276 \pm 0.348$ \\
\hline & & II & 29.70 & 29.90 & $29.800 \pm 0.100$ & 20.52 & 22.52 & $21.523 \pm 1.000$ & 6.48 & $\begin{array}{l}7.04 \\
7.00\end{array}$ & $6.743 \pm 0.260$ \\
\hline & & III & 29.05 & 29.15 & $29.100 \pm 0.050$ & 17.45 & 21.45 & $19.45 \pm 2.00$ & 10.50 & 11.62 & $11.082 \pm 0.561$ \\
\hline & & IV & 28.00 & 30.00 & $29.033 \pm 1.002$ & 18.12 & 22.12 & $20.12 \pm 2.00$ & 10.56 & 12.56 & $11.563 \pm 1.000$ \\
\hline
\end{tabular}

${ }^{* *}$ probability value $>0.001$.

\section{2. $\mathrm{NO}_{3}-\mathrm{N}$ Removal under Different $\mathrm{NO}_{3}-\mathrm{N} / \mathrm{NH}_{4}-\mathrm{N}$ Ratios}

Figures 3 and 4 show $\mathrm{NO}_{3}-\mathrm{N}$ removal in Setups 1 and 2 under different $\mathrm{NO}_{3}-\mathrm{N} / \mathrm{NH}_{4}-\mathrm{N}$ ratios. In the first setup, the $\mathrm{NO}_{3}-\mathrm{N}$ removal rate was $18.77 \%, 29.36 \%, 30.60 \%$, and $33.01 \%$ in the CFW bed and $65.07 \%, 68.67 \%, 55.10 \%$, and $53.41 \%$ in the HFCW bed. In Setup 2, removal efficiency was $38.04 \%$, $49.68 \%, 46.31 \%$, and $58.10 \%$ for the first bed and $56.55 \%, 63.47 \%, 56.48 \%$, and $48.63 \%$ for the second bed. In both cases, there was a significant difference $(p<0.05)$ between the hybrid system beds in both setups.

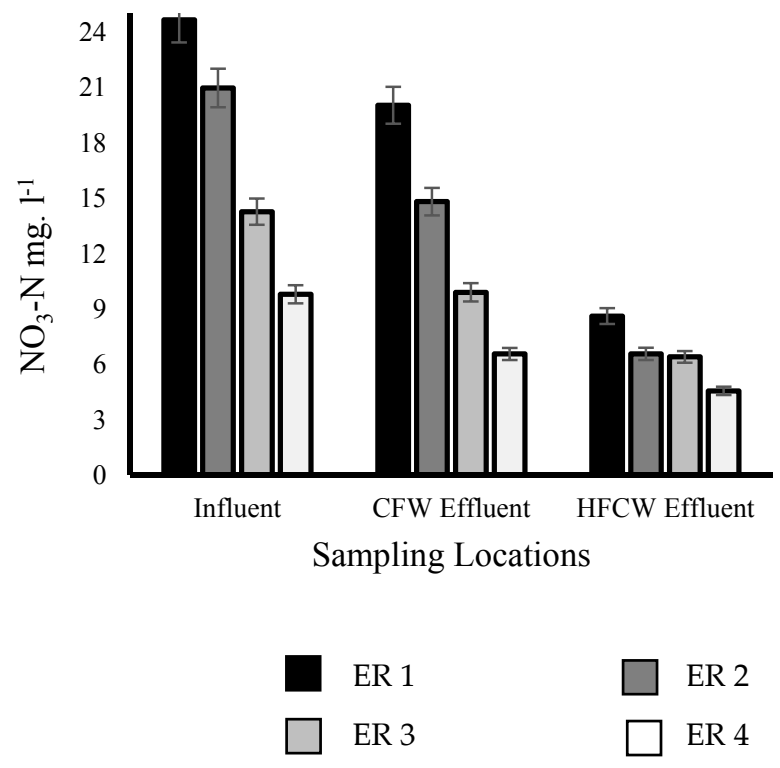

Figure 3. $\mathrm{NO}_{3}-\mathrm{N}$ concentration during different experimental runs in the first setup. 


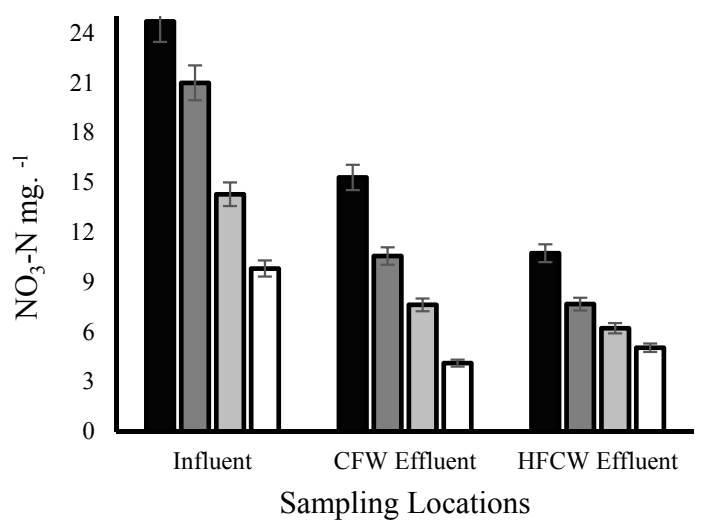

$\begin{array}{ll}\text { ER } 1 & \square \quad \text { ER } 2 \\ \square \quad \text { ER 3 } & \square \quad \text { ER } 4\end{array}$

Figure 4. $\mathrm{NO}_{3}-\mathrm{N}$ concentration during different experimental runs in the second setup.

\subsection{Total Nitrogen Removal under Different NO3-N/NH4-N Ratios}

Figure 5 reveals that there is no significant difference in the total nitrogen removal between both $\mathrm{CW}$ beds in both setups under different $\mathrm{NO}_{3}-\mathrm{N} / \mathrm{NH}_{4}-\mathrm{N}$ ratios. The values were as follows: for Setup 1, 32.73\%, 26.81\%, 34.05\%, and 32.65\%, and 73.07\%, 77.06\%, 63.04\%, and $61.22 \%$ for Beds 1 and 2, respectively; for Setup 2, 34.91\%, 37.74\%, $47.99 \%$, and $45.18 \%$ and $63.59 \%, 69.17 \%, 59.05 \%$, and $59.33 \%$ for Beds 1 and 2, respectively.
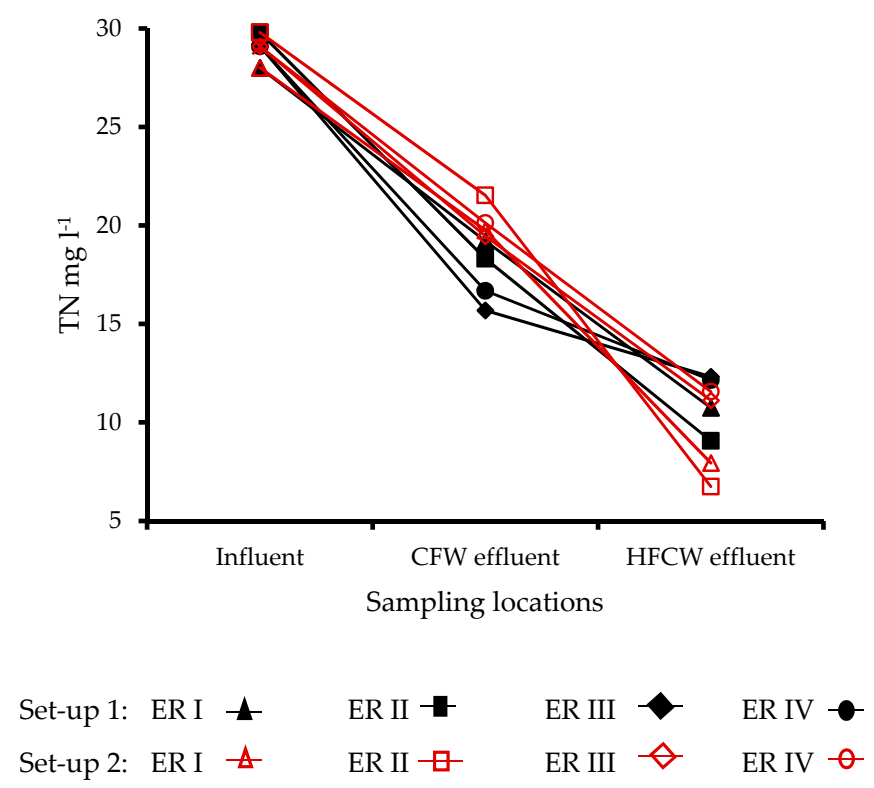

Figure 5. Total nitrogen concentration during different experimental runs in the first and second setups.

\section{Discussion}

The $\mathrm{NO}_{3}-\mathrm{N} / \mathrm{NH}_{4}-\mathrm{N}$ ratio has great significance in constructed wetland systems by affecting plant growths [34]. For optimum uptake and growth, each plant species requires a different amount of $\mathrm{NO}_{3}-\mathrm{N} / \mathrm{NH}_{4}-\mathrm{N}$ ratio [35]. Most of the plants grew well when they were provided by a mixture of $\mathrm{NO}_{3}-\mathrm{N}$ and $\mathrm{NH}_{4}-\mathrm{N}$ rather than either of these components alone [36,37]. A. calamus, L. esculentum, and $C$. sativus grew well and achieved the highest dry weight under a $\mathrm{NO}_{3}-\mathrm{N} / \mathrm{NH}_{4}-\mathrm{N}$ ratio of 1:1, and higher amounts of $\mathrm{NO}_{3}-\mathrm{N}$ suppressed growth [24-26]. Nitrogen removal in the constructed 
wetland system includes adsorption by the substrate, plant uptake, nitrification, and volatilization [38]. Many researchers stated that, in a constructed wetland system, little $\mathrm{NH}_{4}-\mathrm{N}$ removal occurs through the direct absorption by plants [39] and it is mostly removed through microbial action [40], whereas on higher $\mathrm{pH}$ most of the $\mathrm{NH}_{4}-\mathrm{N}$ is removed by volatilization [41]. The constructed wetland systems can consider a complex bioreactor, various biotic and abiotic factors interact with each other, and a number of physical, chemical and biological processes take place [42].

The effect of $\mathrm{NH}_{4}-\mathrm{N}$ removal under different $\mathrm{NO}_{3}-\mathrm{N} / \mathrm{NH}_{4}-\mathrm{N}$ ratios in hybrid constructed wetland systems was significant, and the removal rate reduces with the decrease in $\mathrm{NO}_{3}-\mathrm{N} / \mathrm{NH}_{4}-\mathrm{N}$ ratio. When the ratio of $\mathrm{NH}_{4}-\mathrm{N} / \mathrm{NO}_{3}-\mathrm{N}$ was $1: 1$, there was little impact on $\mathrm{NH}_{4}-\mathrm{N}$ removal, a possible reason was which being that an insufficient amount of oxygen in the subsurface wetlands limits these processes [43]. For $\mathrm{NO}_{3}-\mathrm{N}$ removal, there is variation between both experimental setups. In the first setup, the surface wetland removed a high concentration of $\mathrm{NO}_{3}-\mathrm{N}$ compared to the subsurface constructed wetland, whereas the second setup showed quite the opposite result. The nitrification processes are effected by $\mathrm{pH}$, temperature, inorganic carbon source, alkalinity, dissolve oxygen, and $\mathrm{NH}_{4}-\mathrm{N}$ concentration [39]. $\mathrm{NH}_{4}-\mathrm{N}$ uptake consumes more oxygen compared to $\mathrm{NO}_{3}-\mathrm{N}$. Ammonium breakdown occurs in roots and reacts with sugar, and this sugar is delivered from leaves to roots, whereas $\mathrm{NO}_{3}-\mathrm{N}$ is transported to leaves and reduces to ammonium and then reacts with sugar [44]. At higher respiration, plants consumes more sugar, leaving less available for $\mathrm{NH}_{4}-\mathrm{N}$ metabolism. S. melongena in the HFCW and I. aquatica in the CFW have well developed root systems, and their oxygen transfer ability is strong, rendering a good aerobic environment around the root system, which ultimately favors nitrifying bacteria and increases the removal ability of $\mathrm{NH}_{4}-\mathrm{N}$.

The rhizome and roots belowground are critical for the removal of nitrogen from wastewater; in the rhizosphere, they provide nutrients and exudates to fuel the microorganisms [45]. The plant root system is an important parameter to consider when selecting plant species for a constructed wetland, as a bigger root area can take up large amount of nutrients and thus improve $\mathrm{N}$ removal.

\section{Conclusions}

- Ipomoea aquatica Forsk. and Solanum melongena L. showed higher removal efficiency for $\mathrm{NH}_{4}-\mathrm{N}$ under higher ammonium concentrations, whereas Allium porrum L. showed higher $\mathrm{NO}_{3}-\mathrm{N}$ removal when $\mathrm{NO}_{3}-\mathrm{N}$ concentrations were high in wastewater. Compared to other vegetables Capsicum annuum L. showed little efficiency for both $\mathrm{N}$ sources.

- $\quad$ The different plants may differ in their capacity to take in $\mathrm{N}$ from different nitrogen sources and therefore should select plants economically so that a constructed wetland can obtain optimum removal of nutrients as well as optimum growth.

- The gap between supply and demand for water and food can be reduced using a constructed wetland for the economical growth of plants, and this approach can broaden the application of a constructed wetland.

Acknowledgments: The authors are thankful to Ministry of Environment, People Republic of China for providing funding for this project. This work was financially supported by the "National 12th Five-Year Major Projects" grant number 2012ZX07101-005.

Author Contributions: Haq Nawaz Abbasi and Xiwu Lu conceived and designed the project, materials, and analysis tools. Haq Nawaz Abbasi performed the experimental works and data analysis. Xiwu Lu supervised the study during all stages. All authors wrote the paper.

Conflicts of Interest: The authors declare no conflict of interest.

\section{References}

1. Igbinosa, E.; Okoh, A. Impact of discharge wastewater effluents on the physico-chemical qualities of a receiving watershed in a typical rural community. Int. J. Environ. Sci. Technol. 2009, 6, 175-182. [CrossRef] 
2. Massoud, M.A.; Tarhini, A.; Nasr, J.A. Decentralized approaches to wastewater treatment and management: Applicability in developing countries. J. Environ. Manag. 2009, 90, 652-659. [CrossRef] [PubMed]

3. Wilkoff, B.L.; Bello, D.; Taborsky, M.; Vymazal, J.; Kanal, E.; Heuer, H.; Hecking, K.; Johnson, W.B.; Young, W.; Ramza, B. Magnetic resonance imaging in patients with a pacemaker system designed for the magnetic resonance environment. Heart Rhythm 2011, 8, 65-73. [CrossRef] [PubMed]

4. Xu, Q.; Chen, S.; Huang, Z.; Cui, L.; Wang, X. Evaluation of organic matter removal efficiency and microbial enzyme activity in vertical-flow constructed wetland systems. Environments 2016, 3, 26. [CrossRef]

5. Abbasi, H.N.; Lu, X.; Xu, F.; Xie, J. Wastewater treatment strategies in china: An overview. Sci. Lett. 2016, 4, 15-25.

6. Jing, S.-R.; Lin, Y.-F.; Lee, D.-Y.; Wang, T.-W. Nutrient removal from polluted river water by using constructed wetlands. Bioresour. Technol. 2001, 76, 131-135. [CrossRef]

7. Kaseva, M. Performance of a sub-surface flow constructed wetland in polishing pre-treated wastewater-A tropical case study. Water Res. 2004, 38, 681-687. [CrossRef] [PubMed]

8. Lee, C.-Y.; Lee, C.-C.; Lee, F.-Y.; Tseng, S.-K.; Liao, C.-J. Performance of subsurface flow constructed wetland taking pretreated swine effluent under heavy loads. Bioresour. Technol. 2004, 92, 173-179. [CrossRef] [PubMed]

9. Wallace, S.; Kadlec, R. Btex degradation in a cold-climate wetland system. Water Sci. Technol. 2005, 51, 165-171. [PubMed]

10. Maine, M.; Sune, N.; Hadad, H.; Sánchez, G. Temporal and spatial variation of phosphate distribution in the sediment of a free water surface constructed wetland. Sci. Total Environ. 2007, 380, 75-83. [CrossRef] [PubMed]

11. Ahmed, S.; Popov, V.; Trevedi, R.C. Constructed wetland as tertiary treatment for municipal wastewater. In Proceedings of the Institution of Civil Engineers-Waste and Resource Management; Thomas Telford Ltd.: London, UK, 2008; pp. 77-84.

12. Li, X.; Manman, C.; Anderson, B.C. Design and performance of a water quality treatment wetland in a public park in shanghai, china. Ecol. Eng. 2009, 35, 18-24. [CrossRef]

13. Martín, M.; Oliver, N.; Hernández-Crespo, C.; Gargallo, S.; Regidor, M. The use of free water surface constructed wetland to treat the eutrophicated waters of lake l'albufera de valencia (Spain). Ecol. Eng. 2013, 50, 52-61. [CrossRef]

14. Cordell, D.; Drangert, J.-O.; White, S. The story of phosphorus: Global food security and food for thought. Glob. Environ. Chang. 2009, 19, 292-305. [CrossRef]

15. Qadir, M.; Sharma, B.R.; Bruggeman, A.; Choukr-Allah, R.; Karajeh, F. Non-conventional water resources and opportunities for water augmentation to achieve food security in water scarce countries. Agric. Water Manag. 2007, 87, 2-22. [CrossRef]

16. Briones, A.M., Jr.; Okabe, S.; Umemiya, Y.; Ramsing, N.-B.; Reichardt, W.; Okuyama, H. Ammonia-oxidizing bacteria on root biofilms and their possible contribution to $n$ use efficiency of different rice cultivars. Plant Soil 2003, 250, 335-348. [CrossRef]

17. Vasileva, V.; Ilieva, A. Chemical composition, nitrate reductase activity and plastid pigments content in lucerne under the influence of ammonium and nitrate form mineral nitrogen. Agron. Res. 2011, 9, 357-364.

18. Forde, B.G.; Clarkson, D.T. Nitrate and ammonium nutrition of plants: Physiological and molecular perspectives. Adv. Bot. Res. 1999, 30, 1-90.

19. Rayar, A.J.; Van Hai, T. Effect of ammonium on uptake of phosphorus, potassium, calcium and magnesium by intact soybean plants. Plant Soil 1977, 48, 81-87. [CrossRef]

20. Bindraban, P.S.; Dimkpa, C.; Nagarajan, L.; Roy, A.; Rabbinge, R. Revisiting fertilisers and fertilisation strategies for improved nutrient uptake by plants. Biol. Fertil. Soils 2015, 51, 897-911. [CrossRef]

21. Serna, M.; Borras, R.; Legaz, F.; Primo-Millo, E. The influence of nitrogen concentration and ammonium/nitrate ratio on n-uptake, mineral composition and yield of citrus. Plant Soil 1992, 147, 13-23. [CrossRef]

22. Ali, A.; Tucker, T.; Thompson, T.; Salim, M. Effects of salinity and mixed ammonium and nitrate nutrition on the growth and nitrogen utilization of barley. J. Agron. Crop Sci. 2001, 186, 223-228. [CrossRef]

23. Guo, S.; Brück, H.; Sattelmacher, B. Effects of supplied nitrogen form on growth and water uptake of french bean (phaseolus vulgaris 1.) plants. Plant Soil 2002, 239, 267-275. [CrossRef] 
24. Vojtíšková, L.; Munzarová, E.; Votrubová, O.; Řihová, A.; Juřicová, B. Growth and biomass allocation of sweet flag (acorus calamus 1.) under different nutrient conditions. Hydrobiologia 2004, 518, 9-22. [CrossRef]

25. Kotsiras, A.; Olympios, C.; Passam, H. Effects of nitrogen form and concentration on yield and quality of cucumbers grown on rockwool during spring and winter in southern greece. J. Plant Nutr. 2005, 28, 2027-2035. [CrossRef]

26. Juan, L.; Zhou, J.-M.; Duan, Z.-Q. Effects of elevated $\mathrm{CO}_{2}$ concentration on growth and water usage of tomato seedlings under different ammonium/nitrate ratios. J. Environ. Sci. 2007, 19, 1100-1107.

27. Rosen, C.J.; Allan, D.L.; Luby, J.J. Nitrogen form and solution ph influence growth and nutrition of two vaccinium clones. J. Am. Soc. Hortic. Sci. 1990, 115, 83-89.

28. Below, F.E. Nitrogen metabolism and crop productivity. Handb. Plant Crop Physiol. 2002, 2, 385-406.

29. Savvas, D.; Passam, H.; Olympios, C.; Nasi, E.; Moustaka, E.; Mantzos, N.; Barouchas, P. Effects of ammonium nitrogen on lettuce grown on pumice in a closed hydroponic system. HortScience 2006, 41, 1667-1673.

30. Tylova-Munzarova, E.; Lorenzen, B.; Brix, H.; Votrubova, O. The effects of $\mathrm{NH}^{4+}$ and $\mathrm{NO}^{3-}$ on growth, resource allocation and nitrogen uptake kinetics of phragmites australis and glyceria maxima. Aquat. Bot. 2005, 81, 326-342. [CrossRef]

31. Zhai, Y.-M.; Hou, M.-M.; Shao, X.-H.; Yang, Q. The comprehensive effects of the subsurface drainage on greenhouse saline soil, tomato yield and quality. Adv. J. Food Sci. Technol. 2016, 10, 691-694.

32. Zhang, Y.; Lin, X.; Zhang, Y.; Zheng, S.J.; Du, S. Effects of nitrogen levels and nitrate/ammonium ratios on oxalate concentrations of different forms in edible parts of spinach. J. Plant Nutr. 2005, 28, 2011-2025. [CrossRef]

33. Federation, W.E.; Association, A.P.H. Standard Methods for the Examination of Water and Wastewater; American Public Health Association (APHA): Washington, DC, USA, 2005.

34. Petrucio, M.; Esteves, F. Uptake rates of nitrogen and phosphorus in the water by eichhornia crassipes and salvinia auriculata. Revista Brasileira de Biologia 2000, 60, 229-236. [CrossRef] [PubMed]

35. Santamaria, P.; Elia, A.; Parente, A.; Serio, F. Fertilization strategies for lowering nitrate content in leafy vegetables: Chicory and rocket salad cases. J. Plant Nutr. 1998, 21, 1791-1803. [CrossRef]

36. Mengel, K.; Kirkby, E.A.; Kosegarten, H.; Appel, T. Nitrogen. In Principles of Plant Nutrition; Springer: Berlin, Germany, 2001; pp. 397-434.

37. Zhang, F.C.; Kang, S.Z.; Li, F.S.; Zhang, J.H. Growth and major nutrient concentrations in brassica campestris supplied with different $\mathrm{NH}^{4+} / \mathrm{NO}^{3-}$ ratios. J. Integr. Plant Biol. 2007, 49, 455-462. [CrossRef]

38. Vymazal, J. Removal of nutrients in various types of constructed wetlands. Sci. Total Environ. 2007, 380, 48-65. [CrossRef] [PubMed]

39. Lee, C.G.; Fletcher, T.D.; Sun, G. Nitrogen removal in constructed wetland systems. Eng. Life Sci. 2009, 9, 11-22. [CrossRef]

40. Lv, T.; Zhang, Y.; Carvalho, P.N.; Zhang, L.; Button, M.; Arias, C.A.; Weber, K.P.; Brix, H. Microbial community metabolic function in constructed wetland mesocosms treating the pesticides imazalil and tebuconazole. Ecol. Eng. 2017, 98, 378-387. [CrossRef]

41. Picot, B.; El Halouani, H.; Casellas, C.; Moersidik, S.; Bontoux, J. Nutrient removal by high rate pond system in a mediterranean climate (France). Water Sci. Technol. 1991, 23, 1535-1541.

42. Singh, S.; Kaushik, A.; Kaushik, C. Comparing efficacy of down-flow and up-flow vertical constructed wetlands for treatment of simulated dumpsite leachate. Imp. J. Interdiscip. Res. 2016, 2, 942-945.

43. Tang, X.; Huang, S.; Scholz, M. Nutrient removal in wetlands during intermittent artificial aeration. Environ. Eng. Sci. 2008, 25, 1279-1290. [CrossRef]

44. Devaux, C.; Baldet, P.; Joubès, J.; Dieuaide-Noubhani, M.; Just, D.; Chevalier, C.; Raymond, P. Physiological, biochemical and molecular analysis of sugar-starvation responses in tomato roots. J. Exp. Bot. 2003, 54, 1143-1151. [CrossRef] [PubMed]

45. Stottmeister, U.; Wießner, A.; Kuschk, P.; Kappelmeyer, U.; Kästner, M.; Bederski, O.; Müller, R.; Moormann, H. Effects of plants and microorganisms in constructed wetlands for wastewater treatment. Biotechnol. Adv. 2003, 22, 93-117. [CrossRef] [PubMed]

(C) 2017 by the authors. Licensee MDPI, Basel, Switzerland. This article is an open access article distributed under the terms and conditions of the Creative Commons Attribution (CC BY) license (http:/ / creativecommons.org/licenses/by/4.0/). 